MORALES RGF; RESENDE LV; MALUF WR; PERES LEP; BORDINI IC. 2015. Selection of tomato plant families using characters related to water deficit resistance. Horticultura Brasileira 33: 027-033. DOI - http://dx.doi.org/10.1590/S0102-053620150000100005

\title{
Selection of tomato plant families using characters related to water deficit resistance
}

\author{
Rafael GF Morales ${ }^{1}$; Luciane V Resende²; Wilson R Maluf²; Lázaro EP Peres ${ }^{3}$; Isadora C Bordini² \\ ${ }^{1}$ EPAGRI, EEItajaí, C. Postal 277, 88318-112 Itajaí-SC; rafaelmorales@epagri.sc.gov.br; ${ }^{2}$ UFLA, Depto. Agricultura, C. Postal

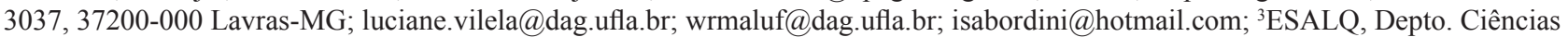 \\ Biológicas, C. Postal 09, 13418-900 Piracicaba-SP; lazaro.peres@usp.br
}

\begin{abstract}
Environmental stress, such as drought stress, constantly cause production loss. Breeding programs search for genotypes which may overcome climate adversities, producing in ideal as well as in stressful environments. The present work aimed at to evaluate parameters related to water deficit in $20 \mathrm{~F}_{3} \mathrm{RC}_{1}$ families of tomato plants derived from the crossing with a (WELL) genotype, originated from a drought resistant species, as well as select plants using characters related to water deficit resistance. The delineation was in randomized blocks design with three replications. Two experiments were carried out, the first in Lavras, Minas Gerais state, Brazil, that consisted in evaluating nine $\mathrm{F}_{3} \mathrm{RC}_{1}$ families derived from two self-fertilizations of the following crosses: \{TOM-684 x (WELL x M-82)\}. The second experiment was carried out in Ijaci, in the same state, and evaluated the same nine families from the previous experiment and another eleven families obtained from the same crossing. The plants were submitted to water deficit by means of the suspension of irrigation at 35 days after transplanting the seedlings to the field. The families T4, T5, T6, T15, T17 were highlighted regarding fruit production and, among the nine families evaluated in both cultivation environments, the T6 was the most productive, indicating good productive stability. Families T5 and T9 were highlighted for presenting low incidence of blossom-end rot and higher relative water content in leaves. The blossom-end rot incidence and relative water content are good parameter to be indirect selection of plants more resistant to drought.
\end{abstract}

Keywords: Solanum lycopersicum, S. pennellii, water deficit indicators, drought resistance.

\section{RESUMO}

Seleção de famílias de tomateiro utilizando caracteres relacionados à resistência ao déficit hídrico

Estresses ambientais, como o hídrico, constantemente provocam prejuízos na produção vegetal. Programas de melhoramento buscam genótipos que possam superar as adversidades climáticas, produzindo tanto no ambiente tido com o ideal, quanto nos ambientes estressantes. O presente trabalho teve por objetivo avaliar caracteres relacionados à resistência ao déficit hídrico em 20 famílias $\mathrm{F}_{3} \mathrm{RC}_{1}$ de tomateiro (Solanum lycopersicum) advindas do cruzamento com um genótipo (WELL) proveniente da espécie $S$. pennellii, resistente à seca. $\mathrm{O}$ delineamento experimental foi em blocos casualizados com três repetições. Foram realizados dois experimentos, o primeiro em Lavras-MG, que consistiu na avaliação de nove famílias $\mathrm{F}_{3} \mathrm{RC}_{1}$ advindas de duas autofecundações dos cruzamentos \{TOM-684 x (WELL x M-82) $\}$. O segundo experimento foi realizado em Ijaci-MG onde se avaliaram as mesmas nove famílias do experimento anterior $\mathrm{e}$ outras onze famílias obtidas do mesmo cruzamento. As plantas foram submetidas ao déficit hídrico por meio da suspensão da irrigação aos 35 dias após o transplantio das mudas para o campo. As famílias T4, T5, T6, T15, T17 destacaram-se quanto à produção de frutos e, dentre as nove famílias avaliadas nos dois locais de cultivo, a T6 foi a mais produtiva, indicando boa estabilidade produtiva. As famílias T5 e T9 destacaram-se por apresentar baixa incidência de podridão apical e maior conteúdo relativo de água na folha. Tanto a podridão apical como o conteúdo relativo de água, são bons parâmetros para a seleção indireta de plantas mais resistentes à seca.

Palavras-chave: Solanum lycopersicum, S. pennellii, indicadores de déficit hídrico, resistência à seca.

\section{(Recebido para publicação em 19 de abril de 2013; aceito em 8 de agosto de 2014)}

(Received on April 19, 2013; accepted on August 8, 2014)

$\mathrm{T}$ he increasing water scarcity is leading to an increase of food import in various countries. Around 80 countries, that altogether possess $40 \%$ of the world population, already suffer with water scarcity (Hamdy et al., 2003). Agriculture is by far the sector responsible for the largest consumption of fresh water on the planet, given that the expense in agriculture may reach $80 \%$ of the total available water (Condon et al., 2004). In addition to the elevated consumption, the efficiency in its use is very low, remaining below $45 \%$ if not well managed (Hamdy et al., 2003). A few strategies must be adopted to maximize the exploration of water resources, such as changes in crop managing and the development of cultivars more effective in the use of water.

Genetic improvement programs that seek the selection of plants with larger efficiency in water use and resistant even to water deficit have obtained little success due to the complexity of the character, which is controlled by many genes with different effects, and is also affected by the intensity of the stress (Bernier et al., 2008). Although 
resistance to drought is polygenic, some monogenic components may improve plants' efficiency to water use.

For tomato plants and related species, resistance to drought is found in wild species that are capable of growing and reproducing in environments that present minimum water (Torrecillas et al., 1995). This characteristic may, in principal, be introduced into cultivars or strains with good agronomic characteristics (Ashraf, 2010). The cross between these wild species with the cultivated species may be a viable alternative to obtain more effective cultivars in water use. In previous papers, a monogenic component of the wild species resistant to drought, S. pennellii, was introgressed in the cultivar Micro-Tom, obtaining the genotype WELL, "Water Economy Locus in Lycopersicum" (Zsögön, 2012). However, the genotype containing WELL is not yet at a commercial background, requiring studies to verify its practical use for obtaining tomato plant commercial cultivars with larger water efficiency and resistant to drought.

Among the characteristics related to the selection of plants more efficient in water use and resistant to drought, fruit productivity and a few secondary characteristics related to productivity in water deficit conditions must be taken into consideration (Bernier et al., 2008). The plants' response to water deficit is related to a complex network of morphological and physiological changes, which may occur with the reduction of leaf size and leaf abscission (Torrecillas et al., 1996), reduction of water content in the leaf (Hetherington \& Woodward, 2003), stomata closure (Royer, 2001), increase in leaf temperature (Siddique et al., 2001) and increase in the incidence of blossom-end rot (Adams \& Ho, 1993).

To obtain success in a breeding program of this nature, characteristics that facilitate the selection must be identified. Among those, blossom-end rot may be a promising characteristic for being one of the first symptoms to manifest when the tomato plant is in water deficit (Taylor et al., 2004). With the identification of reliable characters and that present practicality in its use, it will be possible to make selection of genotypes with better water use and resistance to water deficit in breeding programs. As such, this work aimed at evaluating characters related to the resistance to water deficit in tomato plant families with WELL (Water Economy Locus in Lycopersicum) background.

\section{MATERIAL AND METHODS}

Two experiments were carried out one in Ijaci, Minas Gerais, Brazil (21 $\left.{ }^{\circ} 9^{\prime} 24^{\prime \prime} \mathrm{S}, 44^{\circ} 55^{\prime} 34^{\prime \prime} \mathrm{W}\right)$, from June to November, and the second in Lavras, Minas Gerais state, Brazil ( $21^{\circ} 14^{\prime} 45^{\prime \prime} \mathrm{S}$, $\left.44^{\circ} 59^{\prime} 59^{\prime \prime} \mathrm{W}\right)$, in the same period as the previous experiment. These experiments were conducted in a protected environment where temperature and maximum and minimum humidity was daily monitored with a digital thermohygrometer (model HTC-1).

The following genotypes are involved in this breeding program: cultivar 82, which possess determined growth and was developed in California University, Davis; TOM-684, which is a commercial strain nearly isogenic to TOM-584, which by its turn derives from the crossing $\{$ (Santa Clara $\mathrm{x}$ Stevens) x Santa Clara $\}$, after selection for tospovirus resistance; and WELL, which derives from the crossing between S. pennellii x Micro-Tom with six backcrosses using Micro-Tom as reoccurring father and selecting for lowest plantwilting velocity.

Both experiments were set in a completely randomized block design with three replicates. Nine $\mathrm{F}_{3} \mathrm{RC}_{1}$ families were evaluated in Lavras (T1: BPX-441B-031, T2: BPX-441B-039, T3: BPX-441B-041, T4: BPX441B-040, T5: BPX-441B-055, T6: BPX-441B-059, T7: BPX-441B-084, T8: BPX-441B-092 and T9: BPX441B-088) originated from two selffertilizations of the following cross: $\{$ TOM-684 x (WELL x M-82)\}. The same nine families and another eleven were tested in Ijaci (T11: BPX441B-022, T12: BPX-441B-013, T13: BPX-441B-020, T14: BPX-441B-025, T15: BPX-441B-044, T16: BPX441B-075, T17: BPX-441B-077, T18:
BPX-441B-083, T19: BPX-441B-007, T20: BPX-441B-008 and T21: BPX441B-019) obtained from the same crossing. In both experiments the mother strain TOM-684 was used as witness (T10), which corresponds to a commercial background. All these families were obtained from the selection of previous generations ( $\mathrm{F}_{1} \mathrm{RC}_{1}$ and $\mathrm{F}_{2} \mathrm{RC}_{1}$ ) for commercial agronomical characteristics, such as plant and fruit size. No selection was made for characteristics related to water deficit resistance.

The seedlings were produced in polystyrene trays with 128 cells, using commercial substrate Plantmax ${ }^{\circledR}$. The seedlings were transplanted at 25 days after sowing, when the seedlings reached about $15 \mathrm{~cm}$ height.

The soil of the experimental area in Lavras is classified as typical distrofferic Red Latosol and presents texture with $33 \%$ sand, $18 \%$ silt and $49 \%$ clay. The soil in Ijaci is classified as dystrophic Red-Yellow Latosol and presents texture with $30 \%$ sand, $15 \%$ silt and 55\% clay.

The soil was prepared one month before the seedling transplanting, by means of aeration followed by liming and harrowing. The beds were raised using roto-tillers and measured 20 $\mathrm{cm}$ height and $1.0 \mathrm{~m}$ length. A soil sample, composed of 10 subsamples, was removed from the 0 to $20 \mathrm{~cm}$ layer for chemical analysis and showed the classification: $\mathrm{pH}\left(\mathrm{H}_{2} \mathrm{O}\right)=4.4$; $\mathrm{H}^{++}+\mathrm{Al}^{+++}=5.05 \mathrm{cmol}_{\mathrm{c}} / \mathrm{dm}^{3} ; \mathrm{Ca}^{++}=$ $3.2 \mathrm{cmol} / \mathrm{dm}^{3} ; \mathrm{Mg}^{++}=0.8 \mathrm{cmol} / \mathrm{dm}^{3}$; $\mathrm{P}($ Mehlich $)=3.1 \mathrm{mg} / \mathrm{dm}^{3} ; \mathrm{K}^{+}=0.15$ cmolc $/ \mathrm{dm}^{3}$; organic matter $=21.00 \mathrm{~g} /$ $\mathrm{dm}^{3} ; \mathrm{CTC}=9.2 \mathrm{cmol}_{\mathrm{c}} / \mathrm{dm}^{3}$; and $\mathrm{V} \%=$ $45.11 \%$. The amount of limestone mixed in the soil one month before planting was $2.5 \mathrm{t} / \mathrm{ha}(\mathrm{V}=70 \%)$, with Relative Power of Total Neutralizing (RPTN) of $92 \%$, calculated based on chemical analysis of the soil. The basic fertilizing was done three days before the transplanting, using $1000 \mathrm{~kg} / \mathrm{ha}$ of 8-28-16 NPK, $360 \mathrm{~kg} / \mathrm{ha}$ of super simple phosphate, $20 \mathrm{~kg} / \mathrm{ha}$ of borax and $20 \mathrm{~kg} /$ ha of zinc sulfate.

The adopted irrigation system was that with self compensating emitters, with a flow rate of $3 \mathrm{~L} / \mathrm{h}$, spacing of 30 $\mathrm{cm}$, using two dripping lines per block 
spaced at $70 \mathrm{~cm}$. The beds were covered by gray polyethylene film (mulching), with $30 \mu \mathrm{m}$ thickness. In Ijaci the mulching remained on the beds until the end of the experiment. In Lavras the mulching was removed 20 days after the beginning of the stress (DABS), aiming to intensify water deficit. The plants were allocated in the beds, forming two lines of five plants, totalizing ten plants per parcel, spaced at $30 \mathrm{~cm}$, given that each plant was positioned exactly between two dripping points.

In Lavras the tutoring of the plants was done with ribbons set in wires at two meters of height. The plants were tied up to the ribbon every three days, and taken to the height of the wire, thus making the pruning. In Ijaci, the adopted tutoring was that supported by stakes (inverted $\mathrm{V}$ ), in which were placed bamboo stakes with 1.80 to $2.20 \mathrm{~m}$ length, supported in a tilted manner on a stretched wire. The plants were tied to the bamboo at 30 to $40 \mathrm{~cm}$ with plastic ribbons. In both locations the side sprouts were eliminated every three days, beginning 15 days after transplanting (DAT) the seedlings and proceeding to the end of the experiment. The sprouts were manually pulled when they presented from one to three $\mathrm{cm}$ length.

One tensiometer was installed per replicate, at the depth of $30 \mathrm{~cm}$, which corresponds to the effective rooting depth of tomato plants. After the seedling transplantation, the beds were daily irrigated during 35 days with 5 $\mathrm{mm}$ /day water irrigation depth, aiming at the best seedling initial development. From this date on the irrigation was suspended, daily monitoring by the measuring of soil water matric potential. As the objective was the selection of water deficit resistance materials, the irrigation would be turned on when the soil presented water tension equal or superior to $80 \mathrm{kPa}$, because above that the tomato plants suffer loss due to water deficit (Sá et al., 2005). However, as no symptoms which characterize water deficit were observed during this period, the irrigation was suspended until the witness (TOM-684) presented symptoms that might be related to water deficit, such as wilting, floral cluster abortion, and height and leaf size reduction. As these symptoms were observed only in an advanced stage of cultivation (35 to 40 DABS or 70 to 75 DAT), irrigation was definitely suspended until the end of the culture cycle (60 to $70 \mathrm{DABS}$ ).

The following evaluations were done: 1) total fruit production per plant (total mass of each plant's fruit, considering the fruits normal and with low blossom-end rot severity, with results expressed in $\mathrm{kg} /$ plant), 2) number of fruits per plant (NFru), (counting the fruits without blossom-end rot of each parcel and dividing by the amount of plants, with results expressed in fruits/ plant), 3) average fruit mass (AFM), (relation between fruit production and NFru, with results expressed in $\mathrm{g}$ /fruit), 4) height of the plants in undetermined growth at $40 \mathrm{DABS}$, 5) leaf temperature $\left({ }^{\circ} \mathrm{C}\right)$ at $35 \mathrm{DABS}$ (with infrared thermometer, using the mean of five readings from leaves from the leaf canopy), and 6) blossom-end rot incidence (\%) in the upper third of the plant (relation between the number of fruits that present blossom-end rot and the total of harvested fruits). According to preliminary results for fruit production, height and blossomend rot incidence in the experiment in Lavras, families T4, T5, T6 and T9 were selected along with the witness $\mathrm{T} 10$, to execute the following evaluations at 65 DABS: 7) foliar area \{relation of mass of a known foliar area (16 foliar discs of $3.18 \mathrm{~cm}$ diameter per parcel) in relation to total fresh mass of the leaves $\}, 8$ ) foliar fresh mass (weighing all green or little senescent leaves manually pulled from four plants per parcel), 9) stem fresh mass (weighing the stem of four plants per parcel). While in Lavras evaluations of families 7 to 9 were done at $64 \mathrm{DABS}$, in Ijaci the plants were conducted until the end of the cycle, executing only analysis 1, 2, 3 and 6 from this date.

The RWC in the leaf was analyzed at four times: 24 hours before induction to water deficit, 15, 30 and 45 DABS. Four leaves from the medium third were removed from each of the eight plants of the parcel and were immediately weighed to determine fresh mass (FM). The same leaves were immersed in distilled water for 24 hours, dried with paper towels and weighed to determine turgid mass (TM). Dry mass (DM) was measured after the leaves were oven dried at $64^{\circ} \mathrm{C}$ for 48 hours. The values were put into the formula described by Scippa et al. (2004):

RWC $(\%)=\{($ FM-DM $) /($ TM-DM $)\} \times 100$.

The data regarding Lavras and Ijaci trials were submitted to variance analysis and the means compared by the Scott-Knott test $(\mathrm{p}<0.05)$. The data referent to the four families selected in Lavras were compared by the Tukey test $(\mathrm{p}<0.05)$.

\section{RESULTS AND DISCUSSION}

Fruit production varied from 1.21 to $3.92 \mathrm{~kg} /$ plant in Lavras and from 1.74 to $4.00 \mathrm{~kg} /$ plant in Ijaci (Tables 1 and 2). Five families were highlighted according to fruit production (T4, T5, T6, T15, T17) and, among the nine families evaluated in both cultivating environments, T6 was the most productive. The T5 family was also highlighted in regard to fruit production in Lavras, however, in Ijaci, the production was inferior to that of the families T4 and T6. In cereal breeding programs, which obtained larger advances in the selection of drought resistance plants, fruit production direct selection under limited water conditions is the most common strategy used by breeders (Bernier et al., 2008). However, the interaction between the genes that confer water deficit resistance and the genes involved in the productive potential per se, which are many, must be taken into consideration (Bernier et al., 2008). As it is impossible to isolate these components, it is not recommended, in the case of the tomato plant, to use fruit productivity separately as a selection parameter, though water deficit does affect it.

The NFru and the AFM, which are the factors that determine the production, are characters that, separately, were not good indicators for the selection of plants more productive under water deficit conditions (Tables 1 and 2). In Lavras, for example, the most productive family (T6) had the same amount of fruits as families T3, T8 and the witness (Table 
Table 1. Effect of water deficit on fruit production (FP), number of fruits per plant (NFru), average fruit mass (AFM), plant height, number of leaves per plant (NLea) and foliar temperature (FT) of nine tomato (Solanum lycopersicum) plant families obtained in the crossing with WELL genotype \{Efeito do déficit hídrico sobre a produção de frutos, número de frutos por planta, massa média de frutos, altura da planta, número de folhas por planta e temperatura foliar de nove famílias de tomateiro (Solanum lycopersicum) obtidas no cruzamento com o genótipo WELL\}. Lavras, UFLA, 2012.

\begin{tabular}{|c|c|c|c|c|c|c|}
\hline Families & FP (kg/plant) & NFru (fruits/plant) & AFM (g/fruit) & Height (cm) & NLea & FT $\left({ }^{\circ} \mathrm{C}\right)$ \\
\hline$\overline{\mathrm{T} 1}$ & $3.22 \mathrm{~b}$ & $34.08 \mathrm{c}$ & $94.16 \mathrm{a}$ & $125.07 \mathrm{~d}$ & $19.60 \mathrm{c}$ & $22.15 \mathrm{~b}$ \\
\hline $\mathrm{T} 2^{\#}$ & $1.21 \mathrm{c}$ & $20.69 \mathrm{~d}$ & $58.27 \mathrm{~b}$ & * & $*$ & $24.42 \mathrm{a}$ \\
\hline $\mathrm{T} 3$ & $2.83 \mathrm{~b}$ & $49.68 \mathrm{~b}$ & $57.08 \mathrm{~b}$ & $129.69 \mathrm{c}$ & $22.02 \mathrm{a}$ & $22.89 \mathrm{a}$ \\
\hline $\mathrm{T} 4$ & $3.92 \mathrm{a}$ & $68.27 \mathrm{a}$ & $57.49 \mathrm{~b}$ & $145.73 \mathrm{a}$ & $22.38 \mathrm{a}$ & $21.58 \mathrm{~b}$ \\
\hline $\mathrm{T} 5$ & $3.60 \mathrm{a}$ & $41.15 \mathrm{c}$ & $87.44 \mathrm{a}$ & $136.99 \mathrm{~b}$ & $20.64 \mathrm{~b}$ & $22.13 \mathrm{~b}$ \\
\hline T6 & $3.90 \mathrm{a}$ & $59.64 \mathrm{~b}$ & $63.44 \mathrm{~b}$ & $135.25 \mathrm{~b}$ & $21.22 \mathrm{~b}$ & $21.43 \mathrm{~b}$ \\
\hline $\mathrm{T} 7^{\#}$ & $1.30 \mathrm{c}$ & $31.58 \mathrm{c}$ & $43.20 \mathrm{c}$ & * - & * $\quad-$ & $23.75 \mathrm{a}$ \\
\hline $\mathrm{T} 8$ & $2.80 \mathrm{~b}$ & $56.48 \mathrm{~b}$ & $50.02 \mathrm{c}$ & $130.71 \mathrm{c}$ & $19.62 \mathrm{c}$ & $20.87 \mathrm{~b}$ \\
\hline $\mathrm{T} 9$ & $2.69 \mathrm{~b}$ & $38.22 \mathrm{c}$ & $70.72 \mathrm{~b}$ & $87.00 \mathrm{e}$ & $18.06 \mathrm{~d}$ & $21.29 \mathrm{~b}$ \\
\hline T10 (witness) & $3.27 \mathrm{~b}$ & $52.65 \mathrm{~b}$ & $62.12 \mathrm{~b}$ & $130.51 \mathrm{c}$ & $19.77 \mathrm{c}$ & $22.23 \mathrm{~b}$ \\
\hline
\end{tabular}

Means followed by the same lowercase letter in the column do not differ among each other statistically by the Scott-Knott test (p $\leq 0.05)$. \#Determined growth families. *Data not measured due to the growth habit of the family \{Médias seguidas pela mesma letra minúscula na coluna não diferem estatisticamente entre si pelo teste de Scott-Knott $(\mathrm{p} \leq 0,05)$. "Famílias de crescimento determinado. *Dados não mensurados devido ao hábito de crescimento da família\}.

Table 2. Effect of water deficit on fruit production (FP), number of fruits per plant (NFru), average fruit mass (AFM), plant height, incidence of blossom-end rot (BER), and foliar temperature (FT) of 20 tomato (Solanum lycopersicum) plant families in the crossing with WELL genotype \{Efeito do déficit hídrico sobre a produção de frutos, número de frutos por planta, a massa média de frutos, altura da planta, incidência de podridão apical e temperatura foliar de 20 famílias de tomateiro (Solanum lycopersicum) obtidas no cruzamento com o genótipo WELL\}. Ijaci, UFLA, 2012.

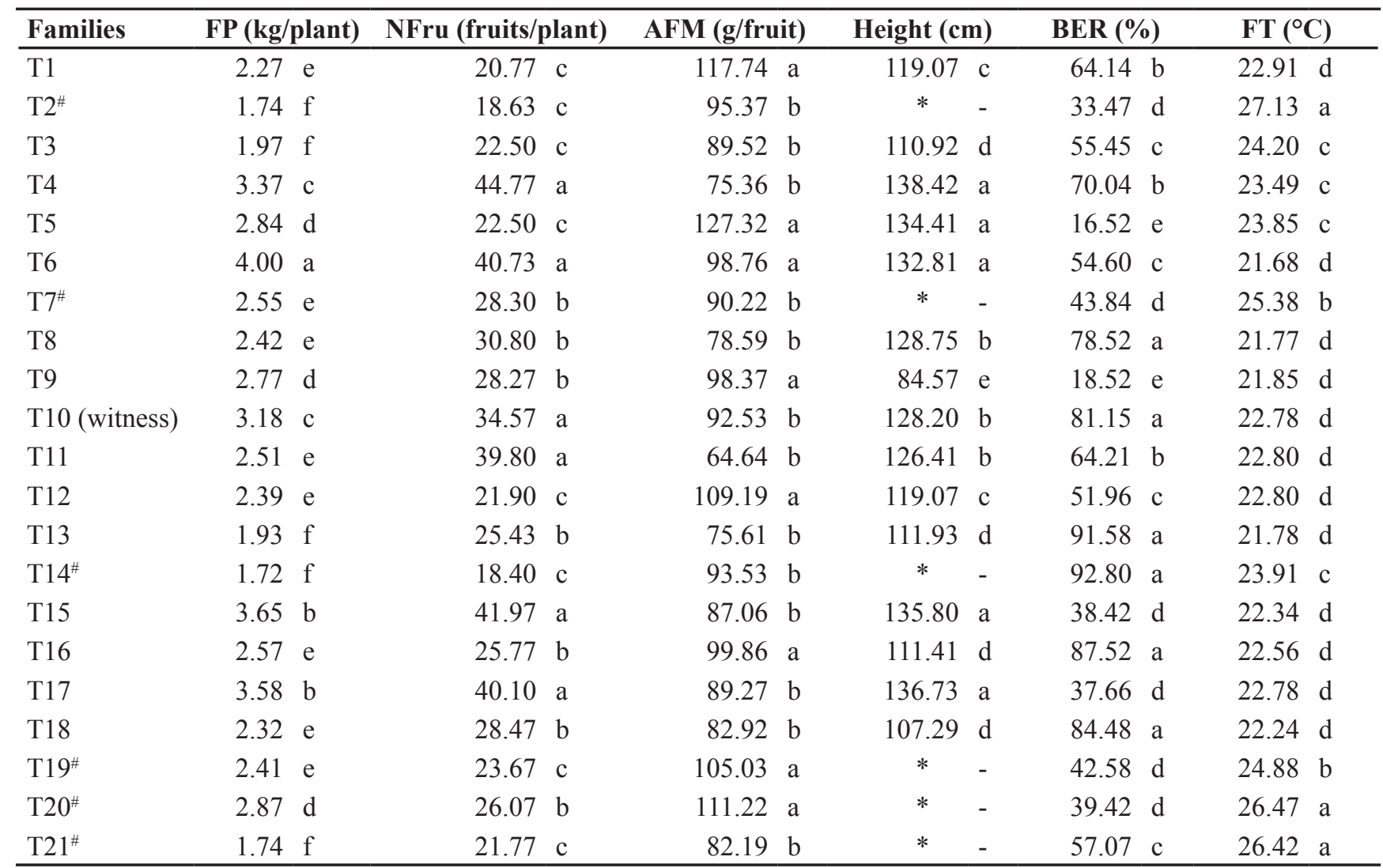

Means followed by the same lowercase letter in the column do not differ among each other statistically by the Scott-Knott test ( $\mathrm{p} \leq 0.05$ ). "Determined growth families. *Data not measured due to the growth habit of the family \{médias seguidas pela mesma letra minúscula na coluna não diferem estatisticamente entre si pelo teste de Scott-Knott $(\mathrm{p} \leq 0,05)$. "Famílias de crescimento determinado. *Dados não mensurados devido ao hábito de crescimento da família\}. 
Table 3. Effect of water deficit over foliar area and blossom-end rot incidence of five tomato (Solanum lycopersicum) plant families obtained in the crossing with WELL genotype \{efeito do déficit hídrico sobre a área foliar e incidência de podridão apical de cinco famílias de tomateiro (Solanum lycopersicum) obtidas no cruzamento com o genótipo WELL\}. Lavras, UFLA, 2012.

\begin{tabular}{lcc}
\hline Families & Foliar area $\left(\mathbf{m}^{\mathbf{2}}\right)$ & Blossom-end rot incidence $\mathbf{( \% )}$ \\
\hline T4 & $2.01 \mathrm{a}$ & $67.47 \mathrm{ab}$ \\
T5 & $1.58 \mathrm{~b}$ & $12.21 \mathrm{c}$ \\
T6 & $1.29 \mathrm{c}$ & $57.49 \mathrm{~b}$ \\
T9 & $0.87 \mathrm{~d}$ & $24.01 \mathrm{c}$ \\
T10 (witness) & $1.56 \mathrm{~b}$ & $80.44 \mathrm{a}$ \\
\hline
\end{tabular}

Means followed by the same lowercase letter in the column do not differ statistically among themselves by the Tukey test $(\mathrm{p} \leq 0.05)$ \{médias seguidas pela mesma letra minúscula na coluna não diferem estatisticamente entre si pelo teste de Tukey $(\mathrm{p} \leq 0,05)\}$.

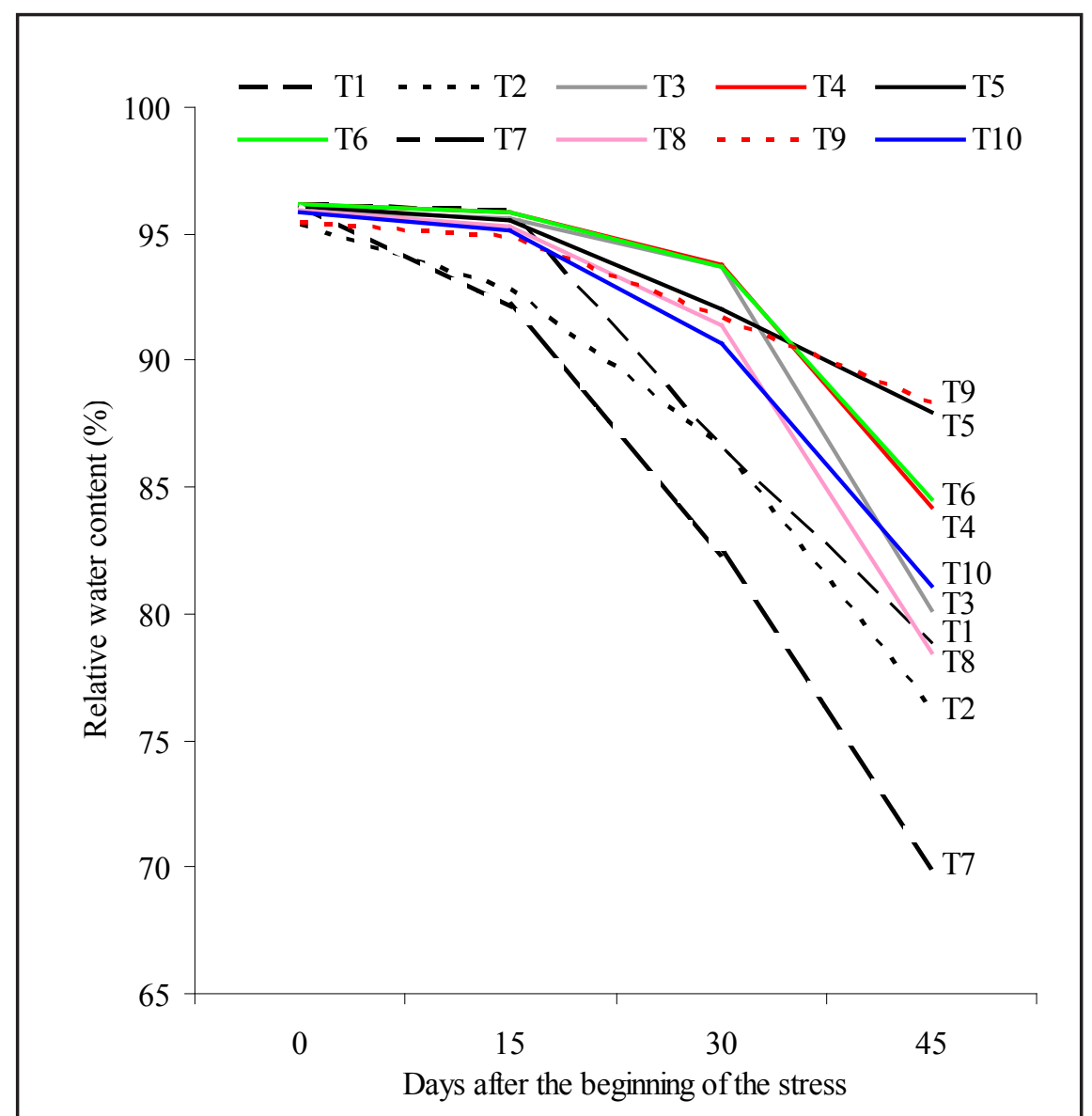

Figure 1. Relative water content in the leaves of ten tomato (Solanum lycopersicum) plant families $\left(\mathrm{F}_{3} \mathrm{RC}_{1}\right)$ obtained in the crossing with WELL genotype \{conteúdo relativo de água em folhas de 10 famílias $\left(\mathrm{F}_{3} \mathrm{RC}_{1}\right)$ de tomateiro (Solanum lycopersicum) obtidas no cruzamento com o genótipo WELL\}. Lavras, UFLA, 2012.

1), which were the less productive undetermined growth families. In Ijaci the same may be observed for AFM, in which the families T1, T5, T9, T12, T16, T19 and T20, which had low productivity, presented equivalent AFM
$\mathrm{F}_{2} \mathrm{RC}_{1}$ ).

Regarding plant height, there were family behavior differences in both cultivating locations. In Lavras, families T4, T5 and T6 which were the most productive were also the tallest, all of them superior to the witness, in height as well as in production (Table 1). In Ijaci, families T4 and T5 did not follow this relation (Table 2), fact that may be related to the tutoring system adopted in Ijaci (inverted V), which made the plants vertical growth and, consequently, the height measuring difficult. This characteristic suffers great effect of the adopted handling system, and can't be configured as a safe parameter for the selection of plant resistance to water deficit. However, growth reduction was observed by Colla et al. (1999) when the tomato plant was submitted to water blade reduction superior to $20 \%$. Under water deficit conditions cellular expansion is more difficult due to the interruption of xylem water flow to the expanding cells (Nonami, 1998), decreasing cellular turgor. With this occurs reduction of growth and loss of characteristics related to production (Hussain et al., 2008).

The T4 family was the only one which presented, at the end of the culture cycle, larger foliar area in relation to the witness, demonstrating great capacity for vegetative development even in severe stress conditions (Table 3 ). However, this did not reflect in productive performance, for the same did not overcome in productivity families T5 and T6 in both cultivation environments. On the other hand, the most productive family (T6) presented smallest foliar area among the most productive families and the witness. Tahi et al. (2008) also observed foliar area reduction in plants submitted to water deficit. The reduction of foliar mass and/ or foliar area is related to the decrease in turgor pressure, provoked by the reduction of the soils' water potential, which reduces cellular expansion (Shao et al., 2008). The reduction of foliar area implies in the decrease of radiation interception, decrease of photosynthesis and, consequently, decreases in dry mass accumulation (Anjum et al., 2011). The difference between the families is 
also related to different $\mathrm{F}_{3} \mathrm{RC}_{1}$ strain backgrounds.

Families T5 and T9 presented levels inferior to $20 \%$ of blossom-end rot. Families T2, T7, T15, T17, T19 and T20 presented intermediate levels of blossom-end rot incidence, varying from 20 to $50 \%$. A third group, composed of 12 families, presented blossom-end rot incidence superior to $50 \%$ (Tables 2). This segregation of $2: 6: 12$ is typical of monogenic inheritance (1/8:2/8:5/8) in generation $\mathrm{F}_{3}$, which is expected in families of WELL genotype genealogy, which has a locus of monogenic inheritance responsible for increasing water use efficiency (Zsögön, 2012).

To obtain success in a breeding program of this nature, characteristics that facilitate selection must be identified. Among these, blossom-end rot may be a promising characteristic for being one of the first problems to manifest when the tomato plant is under water deficit conditions. It is a characteristic of easy measurement and it is mostly related to water deficit (Taylor et al., 2004). The intensification of this problem occurs when the tomato plants are submitted to average soil water tension superior to $81.0 \mathrm{kPa}$ (Sá et al., 2005). In this experiment, 80 $\mathrm{kPa}$ tension was observed at $20 \mathrm{DABS}$. From this date, increase of blossomend rot incidence was expected and, plants which presented lower incidence might be indirectly considered more resistant to water deficit. Therefore, among various characteristics evaluated, blossom-end rot may be the one most intimately related to plant resistance to water deficit, and may integrate strategy of selection of tomato plants resistance to this form of stress. However, other characteristics must be taken into consideration, for blossom-end rot may be influenced by various other factors, such as saline stress (Franco et al., 1999), high temperatures (Ho et al., 1993), physical soil characteristics, cationic balance of the soil solution, relative humidity of the air (Kreij, 1996), among others.

Foliar temperature only discriminated plants of determined and undetermined cycle, due to the fact that they differ in response to water deficit. This fact was observed in Lavras as well as in Ijaci, with temperatures varying from 23.75 to $24.20^{\circ} \mathrm{C}\left(\right.$ mean $\left.=25.3^{\circ} \mathrm{C}\right)$ for plants of determined cycle and from 20.80 to $24.20^{\circ} \mathrm{C}\left(\right.$ mean $=22.4^{\circ} \mathrm{C}$ ) for plants of undetermined cycle, considering both cultivating environments (Tables 1 and 2). The increase of temperature probably occurred due to the decrease in plant transpiration, this being the main cooling mechanism for plants (Siddique et al., 2001). Furthermore, high foliar temperatures have a narrow relation with carbon fixation in the various steps of photosynthesis (Medlyn et al., 2002).

Relative water content is apparently related to lower blossom-end rot incidence, for families T9 and T5, which presented lower blossom-end rot incidence, were also the ones which presented larger RWC at 45 DABS, with approximately $88 \%$ water (Figure 1). The witness presented $81.09 \%$ RWC, higher only than the least productive families (T1, T2, T3, T7 and T8).

The maintenance of foliar turgor in response to water deficit is due to the chemical signaling in the root system, proportioned by abscisic acid or by the apoplastic $\mathrm{pH}$, which induces stomata closing (Hartung et al., 2002; Wilkinson \& Davies, 2008). For cotton, Parida et al. (2008) attributed the increase of RWC to proline accumulation, conferring water deficit resistance to the plant. For Blum (2005), plants in moderate or severe water deficit conditions can maintain cellular turgor by means of osmotic adjustments, which is decrease in osmotic pressure caused by the accumulation of solutes in the cells, which maintains the hydro potential gradient and, at the same time, the turgidity necessary for cellular growth. The maintenance of high RWC is a way of measuring the plant's water state (Anjum et al., 2011), considered by Luo (2010) one of the most important physiological characteristics related to dehydration tolerance mechanisms.

All physiological mechanisms discussed above influenced the plants' response to water deficit, allowing families T5 and T9 to be highlighted in water stress conditions. The blossomend rot incidence and relative water content are good parameters to indirect select plants which are more resistant to drought.

\section{ACKNOWLEDGEMENTS}

To Fundação de Amparo à Pesquisa de Minas Gerais (FAPEMIG), Conselho Nacional de Desenvolvimento Científico e Tecnológico (CNPq), Coordenação de Aperfeiçoamento de Pessoal de Nível Superior (CAPES), for their financial support to the project, to Universidade Federal de Lavras (UFLA) for the technical support, and to Hortiagro Seeds Company for the infrastructure availability.

\section{REFERENCES}

ADAMS P; HO LC. 1993. Effects of environment on the uptake and distribution of calcium in tomato and on the incidence of blossom-end rot. Plant and Soil 154: 127-132.

ANJUM SA; XIE X; WANG L; SALEEM MF; MAN C; LEI W. 2011. Morphological, physiological and biochemical responses of plants to drought stress. African Journal of Agricultural Research 6: 2026-2032.

ASHRAF M. 2010. Inducing drought tolerance in plants: Recent advances. Biotechnology Advances 28: 169-183.

BERNIER J; ATLIN GN; SERRAJ R; KUMAR A; SPANER D. 2008. Breeding upland rice for drought resistance. Journal of the Science of Food and Agriculture 88: 927-939.

BLUM A. 2005. Drought resistance, water-use efficiency, and yield potential: are they compatible, dissonant, or mutually exclusive? Australian Journal of Agricultural Research 56: 1159-1168.

COLLA G; CASA R; LO CASCIO B; SACCARDO F; TEMPERINI O; LEONI C. 1999. Responses of processing tomato to water regime and fertilization in central Italy. Acta Horticulturae 487: 531-535.

CONDON AG; RICHARDS RA; REBETZKE GJ; FARQUHAR GD. 2004. Breeding for high water-use efficiency. Journal of Experimental Botany 55: 2447-2460.

FRANCO JA; PEREZ-SAURA PJ; FERNANDEZ JA; PARRA M; GARCIA AL. 1999. Effect of two irrigation rates on yield, incidence of blossom end rot, mineral content, and free amino acid levels in tomato cultivated under drip irrigation using saline water. The Journal of Horticultural Science and Biotechnology 74: 430-435.

HAMDY A; RAGAB R; SCARASCIAMUGNOZZA E. 2003. Coping with water scarcity: water saving and increasing water productivity. Irrigation and Drainage 52: 3-20.

HARTUNG W; SAUTER A; HOSE E. 2002. 
Abscisic acid in the xylem: Where does it come from, where does it go to? Journal of Experimental Botany 53: 27-32.

HETHERINGTON AM; WOODWARD FI. 2003. The role of stomata in sensing and driving environmental change. Nature 424: 901-908.

HO LC; BELDA R; BROWN M; ANDREWS J; ADAMS P. 1993. Uptake and transport of calcium and the possible causes of blossomend rot in tomato. Journal of Experimental Botany 44: 509-518.

HUSSAIN M; MALIK MA; FAROOQ M; ASHRAF MY; CHEEMA MA. 2008. Improving drought tolerance by exogenous application of glycine betaine and salicylic acid in sunflower. Journal of Agronomy and Crop Science 194: 193-199.

KREIJ C. 1996. Interactive effects of air humidity, calcium and phosphate on blossom-end rot, leaf deformation, production and nutrient contents of tomato. Journal of Plant Nutrition 19: 361-377.

LUO LJ. 2010. Breeding for water-saving and drought-resistance rice (WDR) in China. Journal of Experimental Botany 61: 35093517.

MEDLYN BE; LOUSTAU D; DELZON S. 2002. Temperature responses of parameters of a biochemically based model of photosynthesis. I. Seasonal changes in mature maritime pine (Pinus pinaster). Plant Cell and Environment 25: $1155-1165$
NONAMI H. 1998. Plant water relations and control of cell elongation at low water potentials. Journal of Plant Research 111: 373-382.

PARIDA A; DAGAONKAR V; PHALAK M; AURANGABADKAR L. 2008. Differential responses of the enzymes involved in proline biosynthesis and degradation in drought tolerant and sensitive cotton genotypes during drought stress and recovery. Acta Physiologiae Plantarum 30: 619-627.

ROYER DL. 2001. Stomatal density and stomatal index as indicators of paleoatmospheric $\mathrm{CO}_{2}$ concentration. Review of Palaeobotany and Palynology 114: 1-28.

SÁ NSA; PEREIRA GM; ALVARENGA MAR; MATTIOLI MW; CARVALHO JA. 2005. Behavior of tomato crop under different soil water tensions in a greenhouse. Revista Brasileira de Engenharia Agrícola e Ambiental 9: 341-347.

SCIPPA GS; DI MICHELE M; ONELLI E; PATRIGNANI G; CHIATANTE D; BRAY EA. 2004. The histone-like protein H1-S and the response of tomato leaves to water deficit. Journal of Experimental Botany 55: 99-109.

SHAO HB; CHU LY; JALEEL CA; ZHAO CX. 2008. Water-deficit stress-induced anatomical changes in higher plants. Comptes Rendus Biologies 331: 215-225.

SIDDIQUE MRB; HAMID A; ISLAM MS. 2001. Drought stress effects on water relations of wheat. Botanical Bulletin of Academia Sinica 41: 35-39.

TAHI H; WAHBI S; EL MODAFAR C; AGANCHICH A; SERRAJ R. 2008. Changes in antioxidant activities and phenol content in tomato plants subjected to partial root drying and regulated deficit irrigation. Plant Biosystems 142: 550-562.

TAYLOR MD; LOCASCIO SJ; ALLIGOOD MR. 2004. Blossom-end rot incidence of tomato as affected by irrigation quantity, calcium source, and reduced potassium. HortScience 39: 1110-1115.

TORRECILLAS A; ALARCÓN JJ; DOMINGO R; PLANES J; SÁNCHEZ-BLANCO MJ. 1996. Strategies for drought resistance in leaves of two almond cultivars. Plant Science 118: 135-143.

TORRECILLAS A; GUILLAUME C;ALARCÓN JJ; RUIZ-SÁNCHEZ MC. 1995. Water relations of two tomato species under water stress and recovery. Plant Science 105: 169176.

WILKINSON S; DAVIES WJ. 2008. Manipulation of the apoplastic $\mathrm{pH}$ of intact plants mimics stomatal and growth responses to water availability and microclimatic variation. Journal of Experimental Botany 59: 619-631.

ZSÖGÖN A. 2012. Identification and characterization of a tomato introgression line with reduced wilting under drought. Canberra: University of Canberra. 188p. (Doctor thesis). 